\title{
Morphometric characterization of the Carmen mountain white-tailed deer in Mexico
}

\author{
N.I. Tarqui-Callejas ${ }^{1}$, J.C. Martínez-González ${ }^{1}$, K. G. Logan-López ${ }^{1}$, A. Guerra-Pérez ${ }^{1}$, A. \\ González-Reyna ${ }^{1}$, H. Castillo-Juárez ${ }^{2}$ and E. Cienfuegos-Rivas ${ }^{1}{ }^{*}$ \\ ${ }^{1}$ Unidad Académica Multidisciplinaria Agronomía y Ciencias, División de Estudios de \\ Postgrado e Investigación, Universidad Autónoma de Tamaulipas. CU Adolfo López Mateos, \\ Cd. Victoria, Tam. CP 87149. Tel y Fax: (834)3181721. \\ ${ }^{2}$ Departamento de Producción Agrícola y Animal. Universidad Autónoma Metropolitana, \\ Unidad Xochimilco. Calzada del Hueso 1100, D.F., México 04960 \\ Niver Ivan Tarqui Callejas \\ Juan Carlos Martínez González \\ Karla Gisela Logan López \\ Antonio Guerra-Pérez \\ Arnoldo González Reyna \\ Héctor Castillo-Juárez \\ niver27@hotmail.com \\ imartinez@uat.edu.mx \\ karlalogan@hotmail.com \\ melopsytacus@hotmail.com \\ argonzal@uat.edu.mx \\ hcjuarez@correo.xoc.uam.mx \\ *Correspondence author: Eugenia Cienfuegos -Rivas, ecienfue@uat.edu.mx
}

\begin{abstract}
Carmen mountain white-tailed (Odocoileus virginianus carminis) is one of the 14 white-tailed deer subspecies distributed in Mexico. In the northeastern region, the beef cattle - deer model has been described as a highly successful system of wildlife conservation. In this area, there are three white-tailed deer subspecies whit contiguous distribution polygon (O. $v$. carminis, $O . v$. miquihuanensis and O. v. texanus). Nevertheless, transition areas have not been established, which has affected the proper management and conservation of these populations. The morphometric variability of the O. v. carminis was determined in order to augment the definition of this subspecies of white-tailed deer in Mexico. Morphometric records of 180 deer harvested from 1997 to 2009 were analyzed. These records are from north central Coahuila, a northeastern state of Mexico. Data was analyzed using linear models with age as a covariate to study 8 body and 23 antler variables. Pearson correlations and morphometric trends were estimated. Morphometric variability was found $(\mathrm{P}<0.05)$ for both, body and antler variables. Morphometric trend was positive and highly associated to within year pluvial precipitation. The Carmen Mountain white-tailed deer described in the present study in the Coahuila state (northeastern, Mexico), is similar to the one reported in the U.S. but different from subspecies O.v. texanus.
\end{abstract}

Keywords: antler and body morphometric variability, Carmen Mountain white-tailed deer, Coahuila, Northeast of Mexico.

\section{INTRODUCTION}

In the northeastern region of Mexico, the cattle-deer model that has been described as a highly successful system of wildlife conservation (Heffelfinger, 2006) where four (O. v. texanus, O. v. miquihuanensis, $O$. $v$. carminis and $O$. v. veraecrusis) out of the 14 whitetailed subspecies reported for Mexico are distributed (Halls, 1984).

The Carmen Mountain white-tailed deer (O. $v$. carminis) common name comes from the Carmen
Mountains of northern Coahuila, Mexico, where the first deer was identified by Goldman and Kellogg (1940) and was described in the U.S. population by Krausman and Ables (1981) in the Big Bend National Park, Texas U.S. This subspecies is considered distinct from O.v. couesi, O.v. miquihuanensis, and O.v. texanus subspecies since it has been somehow isolated by its natural mountainous habitat (Heffelfinger, 2006).

In the U.S. this subspecies is found in the Chisos Mountains (an extension of the Carmen Mountains) 
located in the Big Bend Park, and in Mexico, in the Carmen Mountains, several adjacent ranges and in the Burro Mountains, of north-central Coahuila, as well as in several parts of northeastern Chihuahua, covering an area of around 187,028 $\mathrm{Km}^{2}$ (Villarreal, 1995).

The Carmen Mountain deer has been associated with dense cover and free-standing water (Krausman and Ables 1981) and it is mostly found in woodlands rather than in the sotol grassland. Anthony and Smith (1977) reported that in the southeastern Arizona U.S. whitetails were associated with a greater diversity of vegetation types than the observed for the Mule deer (Odocoileus hemionus). Since its wide grazing habits, whitetails have a greater physiological adaptation to a greater variety of vegetation types; hence, it has a wider distribution compared to other deer species (Kramer, 1972).

The first phenotypic description of Carmen deer was done in 1940 by Goldman and Kellogg using the morphometric data of "typical individuals" of this subspecies. Following descriptions were conducted by Krausman and Ables (1981), using data collected in the Big Bend National Park, U.S. and by Logan et al. (2006) and Logan et al. (2007), with data from Coahuila, México. Given the small number of samples used to describe this subspecies, the ranges of body and antler size are difficult to establish. This situation causes that some decisions are difficult to make in big game contest, and considering that there are other three different subspecies which are ranged in adjacent areas, misidentifications are common and could have affected the proper management and conservation of these populations.

The objective of the present study was to characterize and determine the morphometric variability of the $O$. $v$. carminis distributed in the Northeast of Mexico to contribute to the definition of subspecies of white-tailed deer in Mexico.

\section{MATERIALS AND METHODS}

Study area: The present study was conducted at "Rancho La Escondida", located in the north-central region of Coahuila, Mexico (Fig. 1), between $28^{\circ} 56^{\prime}$ $10^{\prime \prime} \mathrm{N}$ latitude and $101^{\circ} 52^{\prime} 30^{\prime \prime} \mathrm{W}$ longitude. The study area encompasses 14,000 ha in the Burro Mountains. The monthly precipitation records were recorded at the study site.

Data: Morphometric records from 180 white-tailed deer males (O. v. carminis) harvested from 1997 to 2009 were analyzed. All records consisted of body and antler measurements (Lundrigan, 1996; Villarreal and Martínez, 1997), with the age estimate based on tooth and molar wear (Jacobson and Reiner 1989) and recorded by the same technician.

Ethics Statement: The production unit is an UMA (Unidad de Manejo para la Conservación de la Vida Silvestre: Wildlife Conservation Unit) that is regulated by the Mexican General Wildlife Law, such that, all animals were handled in strict accordance with good animal practice as defined by the relevant national and/or local animal welfare bodies. No animals were harmed and were handled with respect. All animals measured had a unique tag (harvesting permit) that was authorized by SEMARNAT (Secretaria de Medio Ambiente y Recursos Naturales: Natural Resources and Environment Secretary) a governmental institution that regulate harvesting permits based on population size.

Habitat: Four types of vegetation were identified: 1) submontane shrubland; 2) pine-oak woodland; 3) riparian habitat; and 4) sotol grassland. The site was divided according to the vegetation type and geographical position in the 14,000 ha of the study site. Vegetation sampling was done in July and November 2007 and in May 2008. The sampling technique was based on the method described by Brower et al. (1990). In each vegetation type, 2 samples were collected within $20 \times 20 \mathrm{~m}$ for the woodland strata, $10 \times 10 \mathrm{~m}$ for the shrub land strata, and $2 \times 2 \mathrm{~m}$ for grassland strata. The study site was classified in four regions based on vegetation type and geographical position within the site: grassland $\left(R_{1}\right)$; pine-oak woodland and riparian habitat $\left(R_{2}\right)$; submontane shrubland and pine-oak woodland $\left(R_{3}\right)$; grassland and pine-oak woodland $\left(\mathrm{R}_{4}\right)$.

\section{Morphometric Variables}

Body variables (Fig. 2) were measured based upon the method described by Lundrigan (1996), Villarreal and Martínez (1997): 1) height at shoulder (HS), 2) total length $(T L), 3$ ) tail length $(T A L), 4)$ outside ear length (OEL), 5) skull length before skinning (SL), 6) neck circumference (NC), 7) heart girth (HG), 8) hind hock length (HHL), 9) jaw length (JL), 10) tarsal gland length (GT), 11) body weight in kilograms (Wt-Kg).

Antler variables (Fig. 3) were based on gross measurements (without reduction) (Villarreal and Martínez 1997): 1) inside spread of main beams (D), 2) length of main beam (F; right and left antler), 3 ) length of tines $(\mathbf{G} ; \mathbf{1}, \mathbf{2}, \mathbf{3} \ldots \mathbf{n}$ tines on right and left antler), 4) length of abnormal tines (E; 1,2,3...n abnormal tines on right and left antler), 5) 
circumference between tines $(\mathbf{H} ; \mathbf{1}, \mathbf{2 , 3}, \ldots \mathbf{n}$ at the smallest place between burr and first, first and second,... $n_{i}$ and $n_{j}$ tines on right and left antler, respectively). 6) Total score (TS) is the total sum without reductions of $D$, right and left antler variables and abnormal points. All length measurements were made in $\mathrm{cm}$.

Model: The next fixed effects linear model was used to analyze data

$$
\boldsymbol{\gamma}_{i k}-\boldsymbol{\beta}+\boldsymbol{\rho}_{i}+\boldsymbol{\alpha}_{i}+(\rho \boldsymbol{\alpha})_{i}+\gamma\left(\boldsymbol{X}_{i}-\bar{X}\right)+\sigma_{i j k}
$$

where $\mathbf{Y}_{\mathrm{ijk}}$ is the $\mathrm{k}^{\text {th }}$ body and antler observation in the $j^{\text {th }}$ year and in the $i^{\text {th }}$ harvest site; $\mu$ is the overall mean; $\rho_{i}$ is the $i^{\text {th }}$ harvest site fixed effect; $\alpha_{j}$ is the $j^{\text {th }}$ year fixed effect; $(\rho \alpha)_{i j}$ is the interaction effect between harvest site and year effects; $\gamma\left(X_{i j}-\not{X}\right)$ is

the age effect (as a covariate), and $\varepsilon_{\mathrm{ijk}}$ is the random residual.

Morphometric Trend: Least square means were obtained with the linear model mentioned, and compared with the annual pluvial precipitation measured on the daily basis on the ranch for those animals harvested between 3.5 to 5 years old to determine whether the pluvial precipitation of the previous two years (growing stage) had an effect on body variables evaluated when the animals were considered adults.

Similarity Analysis: A similarity analysis was performed using cluster analysis for the studied morphometry, to compare the morphometric variables reported in the literature with values found in the present study. To determine the similarity, s(ij), between two clusters $i$ and $j$ the next formula (Logan et al., 2006) was used:

$$
s(t)=\frac{100(1-d(t)}{d(\max )}
$$

As $d$ was calculated from data, then $d(\max )=2$.

Pearson correlation: Product-moment correlation was estimated between all pair of variables as $\boldsymbol{r}_{X, Y^{\mathcal{B}}}=\frac{\sigma_{X Y}}{\sigma_{y, \sigma_{Y}}}$, where, $\sigma_{X, Y}$ is the covariance between $\mathrm{x}$ and y; while $\sigma_{X}$ and $\sigma_{Y}$ are the standard deviation for $\mathrm{x}$ and $\mathrm{y}$, respectively.

\section{RESULTS AND DISCUSSION}

Body Measurements: It is important to emphasize that historically there has never been introduction of deer neither O.v. carminis nor other subspecies into the studied area. Given the extension of the production unit and the mountain topography, it can be assumed that the deer population under study has not interbred with other subspecies. The ranch is not high fenced and thus white-tail population moves freely throughout the area.

Group of Age.- For body (NC and HG) and antler (TS; gross and $\mathrm{H} 1$; antler mass, circumference between burr and first tine) measurements, it was found that they increased with age (Table 1) and reached their maximum value at around 6 years of age and then started to decline (Fig. 4). The coefficient of variation (CV) found between groups of age for each of the body morphometric variables was similar. It was observed (Table 1) that, within group of age, NC had the highest CV (12.0\%) in the youngest animals (2.5 to $3.5 \mathrm{yrs}$ ) TL, and $\mathrm{HHL}$ had about the same CV in the three groups evaluated. Because the young adults or sub-adults individuals are still growing, it is expected that variables as NC have not yet reached their maximum growth at this time; also, the amount of fat could be different every year, depending on the food availability.

Two groups of body variables were observed. The first group, included those variables that increased with age $(P<0.05)$, such as $\mathrm{TL}, \mathrm{NC}, \mathrm{HS}$ and HG. The second group included those variables that, on average, did not increase with age $(P>0.05)$, such as TAL, SL, OEL and JL.

Mature animals (>4.5 yrs) (Table 2) were larger (TL) and taller $(\mathrm{HHL})$ than the typical deer described by Goldman and Kellogg (1940) in the Carmen Mountains, Coahuila, Mexico, and than those described by Krausman and Able (1981) in the Big Bend National Park, Texas U.S. and by Logan et al. (2006) in the north central region of Coahuila, Mexico. Even though, morphometric differences were observed between O.V. carminis described in the present study and those ones (O.V. carminis and O.V. texanus) described by Goldman and Kellogg (1940) (Table 2), it was found that morphometry (TL, HS, TAL, OEL, NC and HHL) among group of age (juvenile $<3.5$, young adult from 3.5 to 4.5 and adult $>6.5$ years old, respectively) was about $99.7 \%$ similar to O.v. carminis, being a distinct group from the O.v. texanus (Fig. 5).

Region.- It was found that the deer body morphometric variables were similar $(P>0.05)$ for the 
region $R_{2}, R_{3}$ and $R_{4}$ (Table 3) and different from those ones found in $R_{1} \quad(P<0.05)$. These results demonstrate that, even though the Carmen Mountain deer has been associated with dense cover and free- standing water (Krausman and Ables, 1981) and is mostly found in woodlands rather than in the sotol grassland, it has a great adaptation range to different vegetation types (Kramer, 1972).

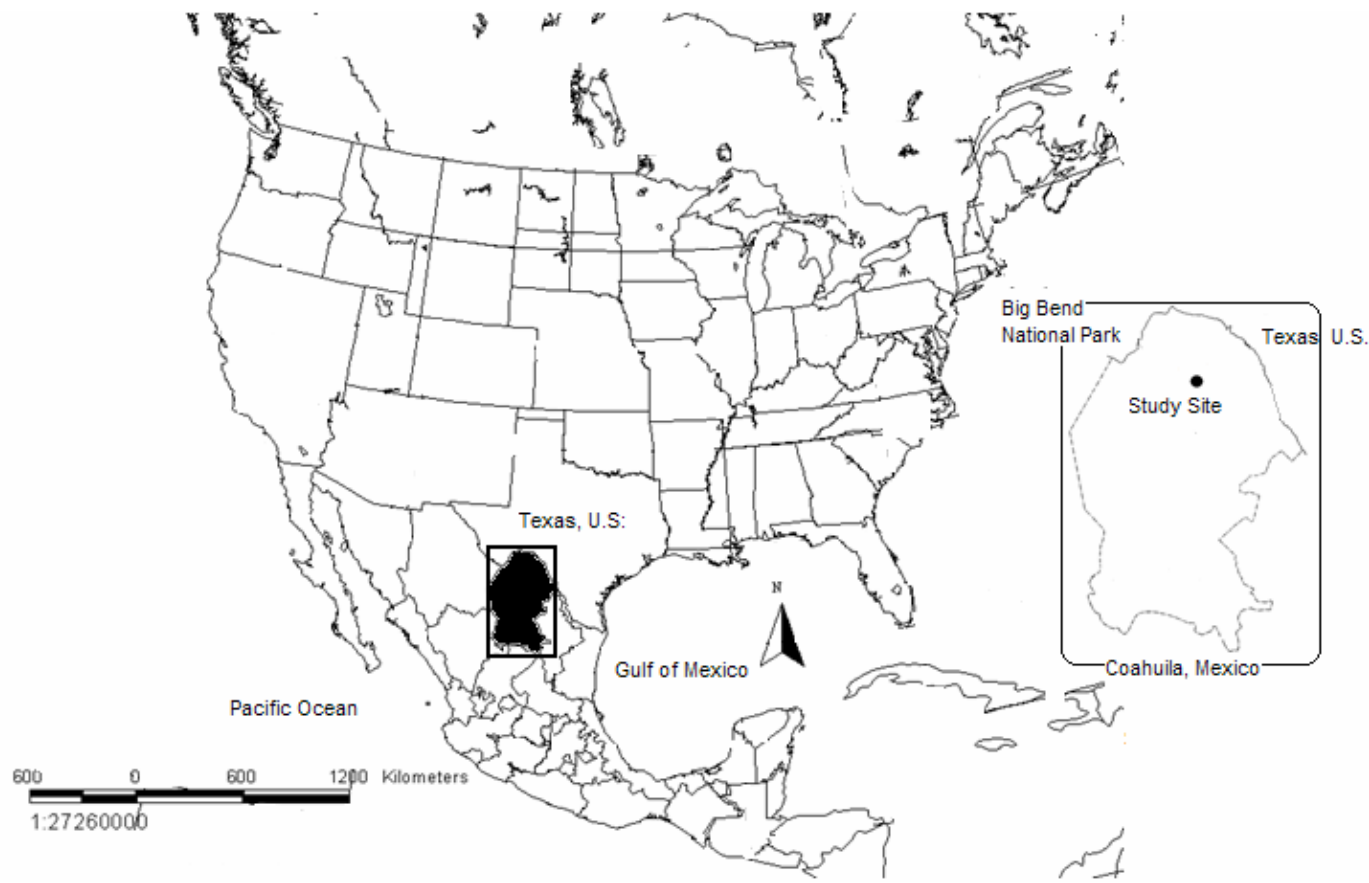

Fig 1. Geographic location of the study site in the north central of Coahuila, Mexico.

Table 1. Body morphometric means for O. v. carminis by group of age (cm).

\begin{tabular}{|c|c|c|c|c|c|c|c|c|c|c|c|c|c|c|c|}
\hline \multirow{4}{*}{ Var } & \multicolumn{15}{|c|}{ Group of Age (yrs) } \\
\hline & \multicolumn{5}{|c|}{$\begin{array}{c}2.5-3.5 \\
\mathrm{~N}=46\end{array}$} & \multicolumn{5}{|c|}{$\begin{array}{c}4.5-5.5 \\
\mathrm{~N}=83\end{array}$} & \multicolumn{5}{|c|}{$\begin{array}{l}>6.5 \\
\mathrm{~N}=49\end{array}$} \\
\hline & \multirow[b]{2}{*}{$x$} & \multirow{2}{*}{ SD } & \multirow{2}{*}{ CV\% } & \multicolumn{2}{|c|}{$\mathrm{Cl}(85 \%)$} & \multirow{2}{*}{$x$} & \multirow{2}{*}{ SD } & \multirow{2}{*}{$\mathrm{CV} \%$} & \multicolumn{2}{|c|}{$\mathrm{Cl}(85 \%)$} & \multirow{2}{*}{$x$} & \multirow{2}{*}{$\mathrm{SD}$} & \multirow{2}{*}{ CV\% } & \multicolumn{2}{|c|}{$\mathrm{Cl}(95 \%)$} \\
\hline & & & & Min & Max & & & & Min & Max & & & & Min & $\operatorname{Max}$ \\
\hline $\mathrm{TL}$ & 164.5 & 7.2 & 4.4 & 162.3 & 166.6 & 165.0 & 7.7 & 4.7 & 183.3 & 168.7 & 167.6 & 8.2 & 4.8 & 165.2 & 169.9 \\
\hline TAL & 22.8 & 3.0 & 13.3 & 20.8 & 24.9 & 21.5 & 2.6 & 12.1 & 20.5 & 22.5 & 23.2 & 2.7 & 11.8 & 20.6 & 25.7 \\
\hline SL & 32.3 & 1.7 & 5.2 & 31.7 & 32.7 & 32.4 & 2.1 & 6.5 & 31.9 & 32.8 & 33.0 & 1.6 & 5.0 & 32.6 & 33.5 \\
\hline OEL & 18.2 & 1.6 & 8.1 & 17.7 & 18.6 & 18.2 & 1.4 & 8.1 & 17.8 & 18.5 & 18.7 & 1.4 & 7.8 & 18.3 & 19.2 \\
\hline NC & 50.3 & 6.0 & 12.0 & 46.2 & 54.4 & 51.0 & 4.4 & 8.6 & 49.4 & 52.6 & 55.7 & 5.3 & 8.5 & 50.7 & 60.6 \\
\hline HS & 82.9 & 3.1 & 3.7 & 81.9 & 83.7 & 84.3 & 3.1 & 3.7 & 83.6 & 84.9 & 85.7 & 3.7 & 4.3 & 84.7 & 86.8 \\
\hline$H G$ & 88.0 & 4.3 & 4.9 & 86.7 & 89.3 & 89.9 & 4.1 & 4.6 & 88.9 & 80.7 & 91.4 & 5.9 & 6.4 & 89.7 & 93.1 \\
\hline $\mathrm{HHL}$ & 43.1 & 1.8 & 4.5 & 41.8 & 44.4 & 43.4 & 2.2 & 5.2 & 42.6 & 44.2 & 44.2 & 2.7 & 6.3 & 41.6 & 46.8 \\
\hline JL & 20.8 & 1.8 & 8.6 & 19.5 & 22.1 & 22.1 & 1.2 & 5.4 & 21.6 & 22.5 & 22.1 & 1.4 & 6.3 & 20.7 & 23.3 \\
\hline TG & 5.3 & 1.6 & 30.1 & 3.8 & 6.7 & 4.7 & 2.9 & 61.7 & 3.6 & 5.8 & 4.8 & 2.6 & 54.1 & 2.3 & 7.2 \\
\hline $\mathrm{Wt}-\mathrm{Kg}$ & 41.0 & 4.9 & 12.0 & 39.6 & 42.6 & 43.9 & 5.0 & 11.5 & 42.8 & 45 & 46.7 & 5.3 & 11.4 & 45.2 & 48.2 \\
\hline
\end{tabular}

Var: varlable; n: number of observations: $\mathrm{Cl}(95 \%) 95 \%$ contdence Interval

$X$ mean; SD: Standard deviation; TL- total length; TAL: tall length; SL: skul length; OEL: outside ear length; NC: neck circumference; HS: helght at shoulders; HG: heart girth; HHL: hind hock length; JL: Jaw length (without skinning); TG: tarsal gland; wit-Kg: body welght in klograms; cm: centimeters. 

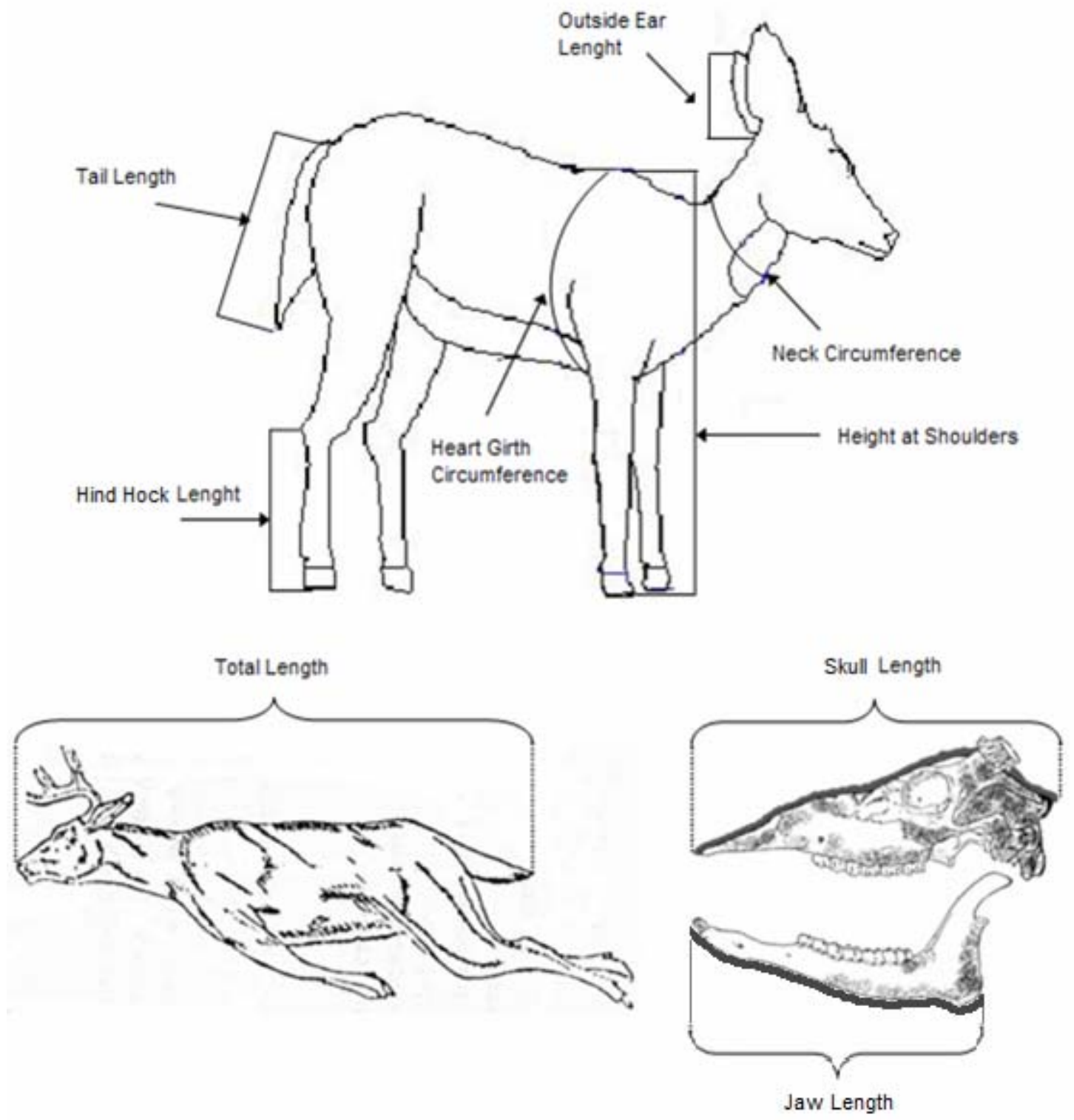

Fig 2. The body variables considered for morphometric characterization of the white-tailed deer carminis (Odocoileus virginianus carminis) in the north central region of Mexico. 
Agric. Biol. J. N. Am., 2011, 2(2): 387-400

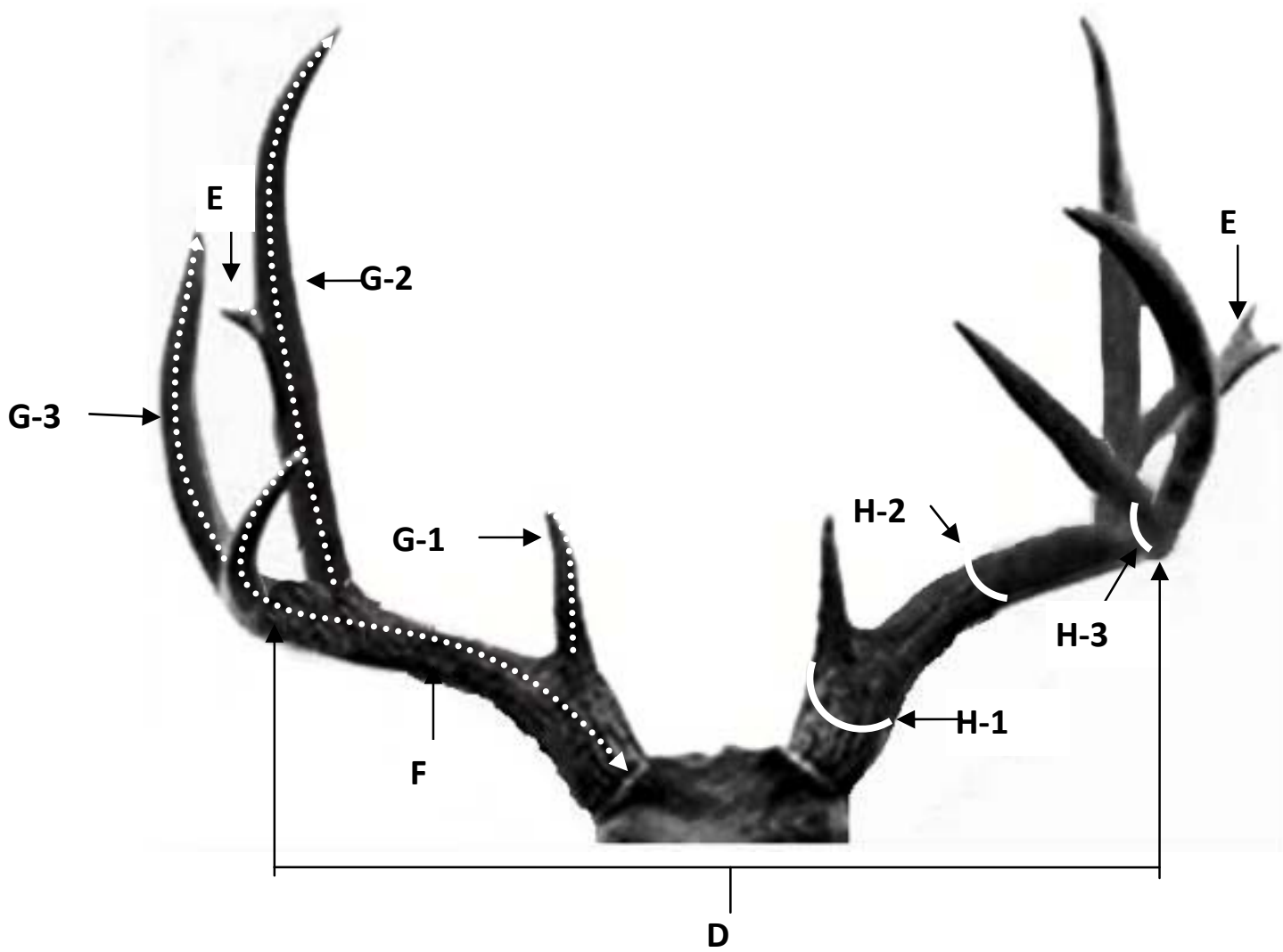

D: Inside spread of main beams, F: Length of main beam right and left antler, G: Length of tines (G; 1,2,3...n tines on right and left antler), $\mathrm{E}$ : Length of abnormal tines ( $\mathrm{E} ; 1,2,3 \ldots \mathrm{n}$ abnormal tines on right and left antler), $\mathrm{H}$ : Circumference between tines $\left(\mathrm{H} ; \mathrm{H}_{1}=\right.$ burr and first, $\mathrm{H}_{2}=$ first and second, $\ldots \mathrm{Hn}=\mathrm{n}_{\mathrm{i}}$ and $\mathrm{n}_{\mathrm{j}}$ tines on right and left antler).

Fig 3. The antler variables considered for morphometric characterization of the white-tailed deer carminis (Odocoileus virginianus carminis) in the north central region of Mexico. 

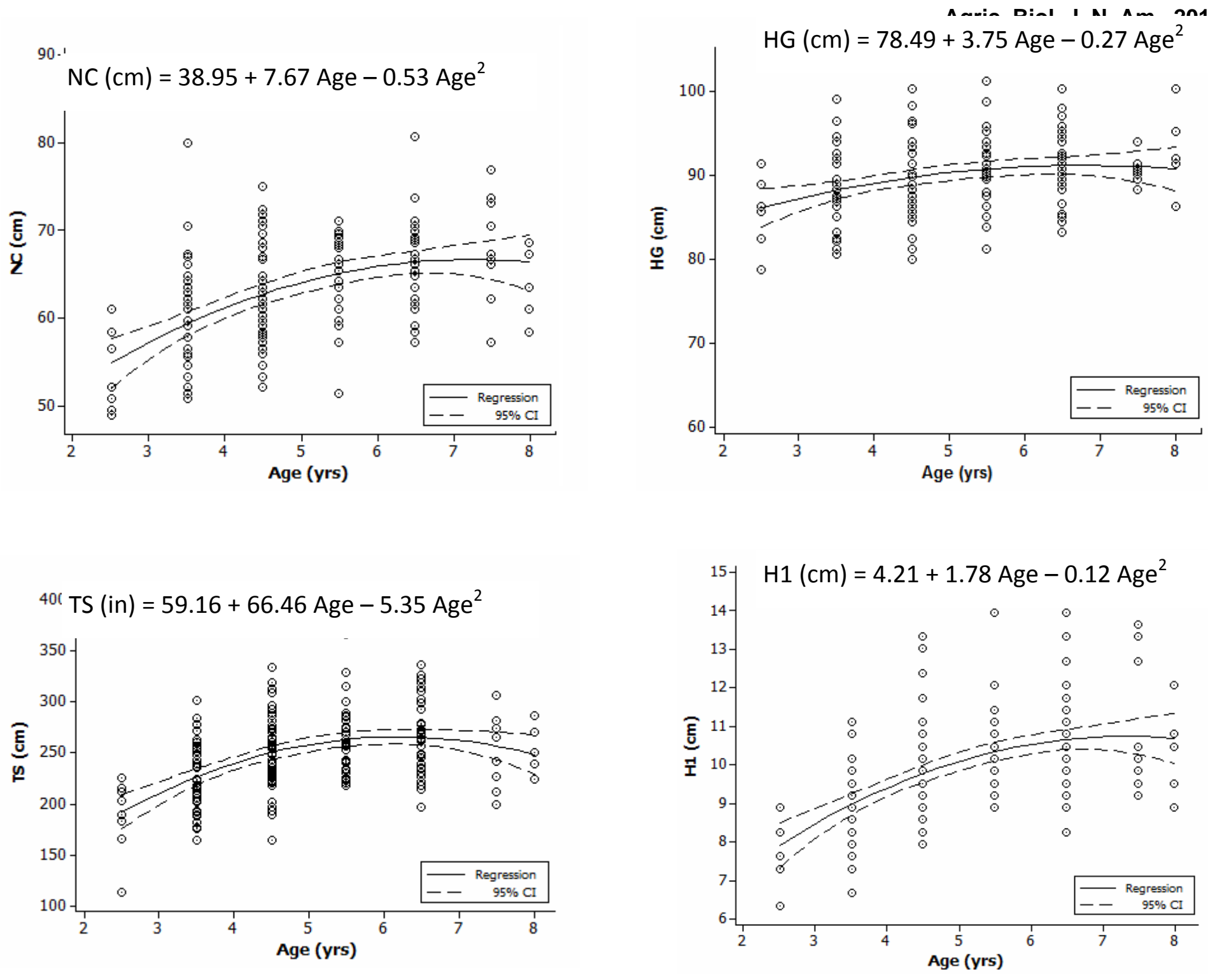

Fig 4. Growth curves for body and antler variables according with age of deer. 


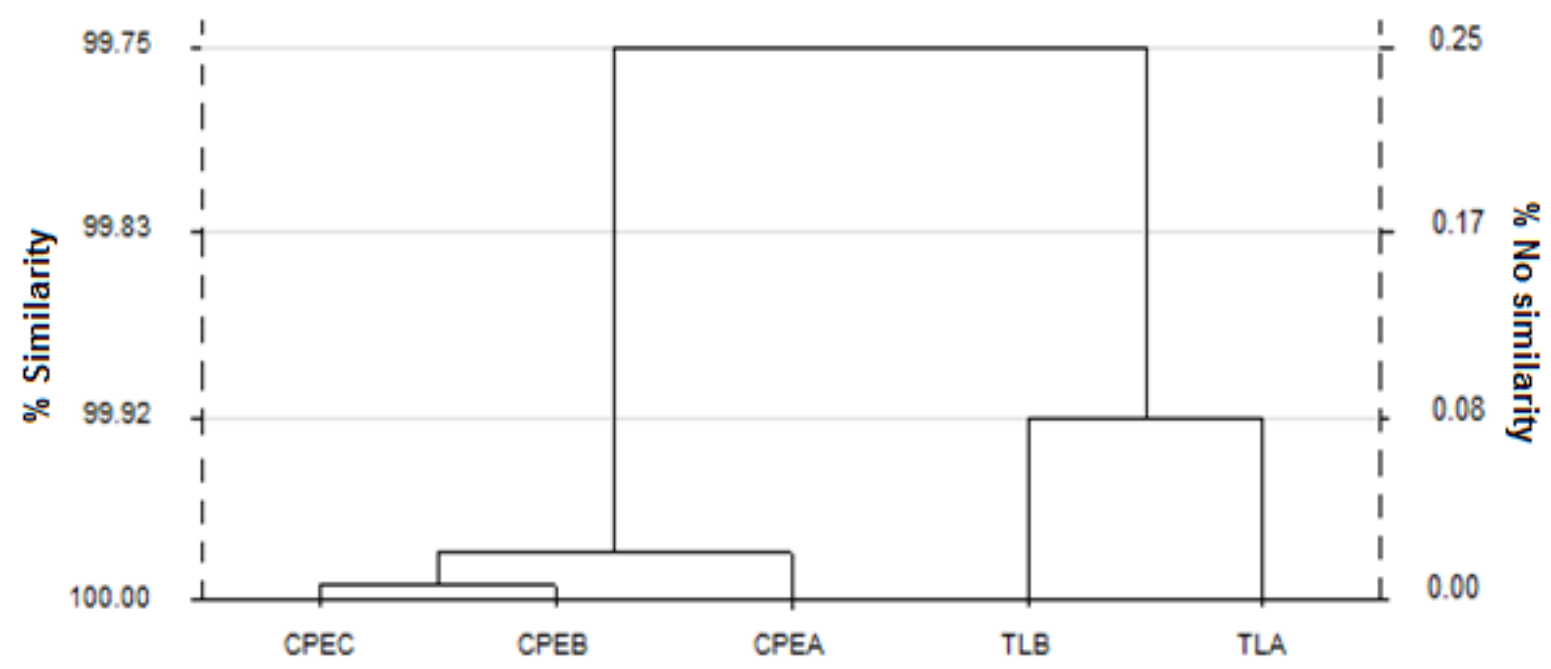

CPEC: $\underline{0 . \text { v. carminis }}$ Present study ( $>6.5$ year) TLB: $\underline{\text { O. v. texanus Logan }(2004)(4.5-5.5 \text { year) }}$

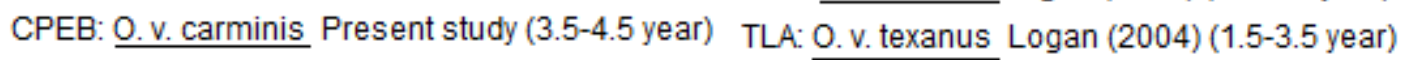

CPEC: $\underline{0 . v \text {. carminis }}$ Present study (1.5-3.5 year)

Fig 5. Percentage of morphometric similarity for body measurements between the $O$. v. carminis, and $O$. v. texanus within group of age observed in this study in the northeast of Mexico and the reported by Logan (2004).

Table 2. Comparison of body morphometric values $(\mathrm{cm})$ of present study with respect to the obtained by four research, in subspecies $O . v$. carminis, $O . v$. covesi and $O$. v. texanus.

\begin{tabular}{|c|c|c|c|c|c|c|c|c|}
\hline Subspecles & TL & TAL & OEL & NC & HS & HHL & SL & Source of data \\
\hline O. v. carminis & 165.1 & 21.8 & 18.2 & 50.9 & 83.8 & 43.4 & $32.3^{*}$ & Present Study" \\
\hline O. v. carminis & 151.2 & 21.3 & & & & 40.3 & 24.2 & $\begin{array}{l}\text { Goldman and Kellogg } \\
(1940)\end{array}$ \\
\hline O. v. carminis & 152.0 & 22.0 & & & 79.3 & 49.0 & 24.1 & Kellogg (1956) \\
\hline O. v. carminis & 145.8 & 18.2 & 17.7 & 37.3 & 83.1 & 41.0 & 25.2 & $\begin{array}{l}\text { Krausman and Ables } \\
\text { (1981) }\end{array}$ \\
\hline O. v. carminis & 147.0 & 23.5 & 17.9 & 48.7 & 83.6 & 39.4 & & Logan et al. (2006) \\
\hline O. v. couesi & 153.0 & 27.0 & & & 89.0 & 41.5 & 24.1 & Kellogg (1956) \\
\hline $\begin{array}{l}\text { O. } v \text {. } \\
\text { miquihuanensis }\end{array}$ & 161.0 & 26.8 & 18.5 & 50.7 & 83.5 & 30.2 & & Logan (2004) \\
\hline O. v. texanus & 182.8 & 25.4 & & & 104.8 & 42.0 & 28.7 & Kellogg (1956) \\
\hline O. v. texanus & 178.3 & 29.3 & 18.2 & 49.4 & 91.8 & 44.1 & 28.3 & Logan et al. (2006) \\
\hline
\end{tabular}

TL: total length; TAL: tall length; OEL: outside ear length; NC: neck circumference; HS: height at shoulders; HHL; hind hock length; SL: skull length; $(\mathrm{cm})$ : centimeters

${ }^{4}$ Data set of $4.5-5.5$ years old animals, $n=132$

" Measurement was obtained of skull without skinning 
Agric. Biol. J. N. Am., 2011, 2(2): 387-400

Table 3. Body morphometric measurements for 0 . v. carminis by harvest site (cm).

\begin{tabular}{|c|c|c|c|c|c|c|c|c|}
\hline \multirow[b]{2}{*}{ Variable } & \multicolumn{2}{|c|}{$\begin{array}{c}\mathrm{R}_{1} \\
\mathrm{n}=40\end{array}$} & \multicolumn{2}{|c|}{$\begin{array}{c}\mathrm{R}_{2} \\
\mathrm{n}=29\end{array}$} & \multicolumn{2}{|c|}{$\begin{array}{c}\mathrm{R}_{3} \\
\mathrm{n}=39\end{array}$} & \multicolumn{2}{|c|}{$\begin{array}{c}\mathrm{R}_{4} \\
\mathrm{n}=36\end{array}$} \\
\hline & $\bar{x}$ & SD & & $S D$ & & SD & & SD \\
\hline TL & 168.89 & 7.65 & 164.40 & 9.08 & 164.89 & 6.90 & 166.43 & 7.35 \\
\hline TAL & 29.93 & 3.32 & 29.53 & 2.62 & 28.93 & 3.10 & 29.82 & 3.26 \\
\hline SL & 33.11 & 1.29 & 32.09 & 2.04 & 32.25 & 1.63 & 32.89 & 1.92 \\
\hline OEL & 18.45 & 1.40 & 18.41 & 1.44 & 18.72 & 1.73 & 18.65 & 1.58 \\
\hline NC & 64.99 & 6.97 & 62.17 & 6.16 & 62.33 & 6.77 & 62.84 & 5.66 \\
\hline HS & 84.73 & 3.51 & 84.10 & 3.33 & 83.91 & 3.18 & 84.14 & 3.29 \\
\hline HG & 91.15 & 5.22 & 88.18 & 6.32 & 89.26 & 3.95 & 89.75 & 4.20 \\
\hline $\mathrm{HHL}$ & 38.45 & 1.90 & 37.84 & 1.95 & 38.34 & 1.95 & 37.73 & 2.18 \\
\hline
\end{tabular}

$\mathbf{R}_{\mathbf{1}}=$ Grassland; $\mathbf{R}_{\mathbf{2}}=$ Pine-oak woodland and riparian habitat; $\mathbf{R}_{\mathbf{3}}=$ submontane shrubland and Pine-oak woodland; $\mathbf{R}_{\mathbf{4}}=$ Grassland and Pine-oak woodland.

TL: total length; TAL: tail length; SL: skull length; OEL: outside ear length; NC: neck circumference; HS: height at shoulders; HG: heart girth; HHL: hind hock length; $\mathrm{cm}$ : centimeters
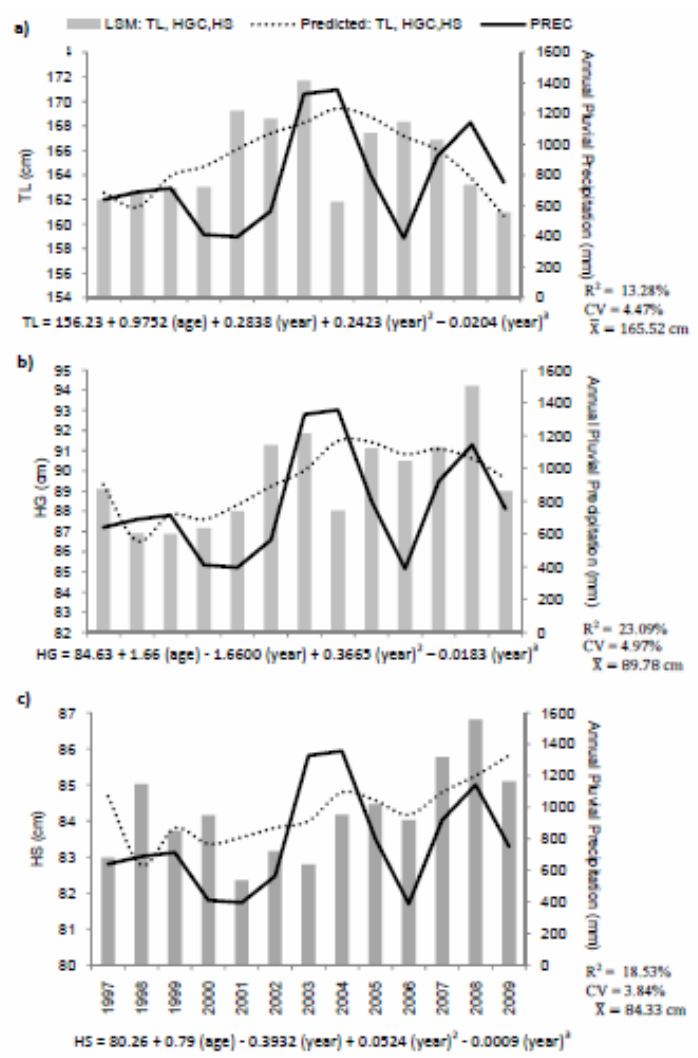

Fig 6. Morphometric trend for body variables related with annual pluvial precipitation. 
Agric. Biol. J. N. Am., 2011, 2(2): 387-400

Table 4. Pearson correlation coefficients among a) body morphometric variables b) antler variables and c) between body and antler variables.

a)

\begin{tabular}{lccccccccc}
\hline & TL & JL & SL & NC & HS & HG & HHL & TG & Wt-Kg \\
\hline JL & $-0.02^{*}$ & & & & & & & & \\
SL & 0.31 & 0.37 & & & & & & & \\
NC & 0.28 & $-0.21^{*}$ & 0.45 & & & & & & \\
HS & 0.27 & 0.51 & 0.15 & 0.32 & & & & & \\
HG & 0.41 & 0.37 & 0.41 & 0.46 & 0.43 & & & & \\
HHL & 0.32 & $0.27^{*}$ & $0.09^{*}$ & 0.21 & 0.41 & 0.22 & & & \\
TG & 0.39 & -0.36 & $-0.14^{*}$ & $-0.32^{*}$ & $-0.05^{*}$ & $-0.18^{*}$ & $-0.24^{*}$ & & \\
Wt-Kg & 0.42 & 0.30 & 0.42 & 0.60 & 0.44 & 0.67 & 0.29 & $-0.15^{*}$ & \\
Age (yrs) & 0.16 & 0.28 & 0.18 & 0.47 & 0.30 & 0.25 & 0.12 & $-0.14^{*}$ & $0.38^{*}$ \\
\hline
\end{tabular}

b)

\begin{tabular}{lcccccc}
\hline & TS & D & F & G1 & H1 & Wt-Kg \\
\hline D & 0.55 & & & & & \\
F & 0.69 & 0.67 & & & & \\
G1 & 0.48 & 0.22 & 0.26 & & & \\
H1 & 0.69 & 0.45 & 0.49 & 0.38 & & \\
Wt-Kg & 0.37 & 0.30 & 0.38 & 0.16 & 0.40 & \\
Age (yrs) & 0.38 & 0.29 & 0.36 & 0.19 & 0.51 & 0.38 \\
\hline
\end{tabular}

c)

\begin{tabular}{lccccccc}
\hline & TL & HG & HS & HHL & TS & F & H1 \\
\hline HG & 0.41 & & & & & & \\
HS & 0.26 & 0.43 & & & & & \\
HHL & 0.32 & 0.22 & 0.41 & & & & \\
TS & 0.18 & 0.33 & 0.25 & 0.16 & & & \\
F & 0.23 & 0.34 & 0.20 & $0.09^{\star}$ & 0.69 & & \\
H1 & $0.08^{*}$ & 0.31 & 0.34 & $0.12^{*}$ & 0.69 & 0.49 & \\
Wt-Kg & 0.42 & 0.67 & 0.44 & 0.29 & 0.37 & 0.38 & 0.40 \\
\hline
\end{tabular}

${ }^{*}$ Correlation coefficients not different from zero $(P>0.05)$.

TL: total length, NC: neck circumference, HS: height at shoulders; HG: heart girth:

HHL: Wt-lb: body weight in kilograms, TS. Total score (Gross), F: Length of main beam,

$\mathrm{H} 1$ : Circumference at smallest place between burr and first tines. 
Agric. Biol. J. N. Am., 2011, 2(2): 387-400

Table 5. Antler morphometric means (in $\mathrm{cm}$ ) for adult (3.5 to $5.5 \mathrm{yrs)}$ O. v. carminis deer in the north east central region of Mexico

\begin{tabular}{|c|c|c|c|c|c|c|c|c|c|c|c|c|}
\hline \multirow[b]{3}{*}{ TS } & \multirow[t]{2}{*}{$\mathrm{n}$} & \multirow{2}{*}{$\overline{\bar{x}}$} & \multirow{2}{*}{$\mathrm{SD}$} & \multirow{2}{*}{ CV (\%) } & \multicolumn{2}{|c|}{$\mathrm{Cl}(95 \%)$} & & & & & & \\
\hline & & & & & Max & Min & & & & & & \\
\hline & 121 & 96.80 & 14.84 & 15.33 & 94.13 & 99.47 & & & & & & \\
\hline \multirow[t]{4}{*}{$\mathrm{D}$} & 121 & 13.53 & 1.85 & 13.67 & 13.19 & 13.86 & & & & & & \\
\hline & \multicolumn{6}{|c|}{ Right Antler } & \multicolumn{6}{|c|}{ Left Antler } \\
\hline & \multirow{2}{*}{$\mathrm{n}$} & \multirow[t]{2}{*}{$\overline{\mathrm{x}}$} & \multirow{2}{*}{$\mathrm{SD}$} & \multirow{2}{*}{ CV (\%) } & \multicolumn{2}{|c|}{$\mathrm{Cl}(95 \%)$} & \multirow[t]{2}{*}{$n$} & \multirow[t]{2}{*}{$\overline{\mathrm{x}}$} & \multirow[t]{2}{*}{ SD } & \multirow[t]{2}{*}{ CV (\%) } & \multicolumn{2}{|c|}{$\mathrm{Cl}(95 \%)$} \\
\hline & & & & & Max & Min & & & & & Max & Min \\
\hline $\mathrm{F}$ & 121 & 16.23 & 2.26 & 13.93 & 15.82 & 16.63 & 121 & 16.37 & 2.11 & 12.91 & 15.99 & 16.75 \\
\hline G1 & 118 & 2.68 & 0.88 & 32.74 & 2.52 & 2.84 & 115 & 2.76 & 0.87 & 31.56 & 2.6 & 2.92 \\
\hline $\mathrm{G} 2$ & 121 & 5.93 & 1.58 & 26.71 & 5.64 & 6.21 & 120 & 5.90 & 1.49 & 25.33 & 5.62 & 6.16 \\
\hline G3 & 116 & 5.14 & 1.71 & 33.30 & 4.82 & 5.45 & 116 & 5.00 & 1.81 & 36.15 & 4.67 & 5.33 \\
\hline G4 & 27 & 2.54 & 1.16 & 45.76 & 2.07 & 2.99 & 26 & 3.12 & 1.59 & 50.98 & 2.47 & 3.75 \\
\hline--- & $\ldots$ & -- & -- & ---- & 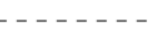 & $\ldots$ & $\cdots$ & --- & --- & ------ & ----- & ------ \\
\hline $\mathrm{H} 1$ & 121 & 3.81 & 0.507 & 13.31 & 3.71 & 3.89 & 121 & 3.80 & 0.47 & 12.43 & 3.71 & 3.88 \\
\hline $\mathrm{H} 2$ & 120 & 3.37 & 0.44 & 13.12 & 3.28 & 3.44 & 120 & 3.33 & 0.40 & 12.04 & 3.26 & 3.40 \\
\hline $\mathrm{H} 3$ & 117 & 3.17 & 0.48 & 15.27 & 3.08 & 3.26 & 116 & 3.17 & 0.51 & 15.99 & 3.07 & 3.26 \\
\hline $\mathrm{H} 4$ & 28 & 3.00 & 0.42 & 14.16 & 2.83 & 3.16 & 28 & 3.17 & 0.54 & 16.97 & 2.95 & 3.37 \\
\hline E1 & 16 & 1.86 & 0.62 & 33.41 & 1.52 & 2.19 & 15 & 2.37 & 1.30 & 54.84 & 1.64 & 3.08 \\
\hline E2 & 4 & 3.75 & 1.78 & 47.52 & 0.91 & 6.58 & 3 & 2.58 & 0.97 & 37.59 & 0.17 & 4.99 \\
\hline
\end{tabular}

TS. Total score (Gross)

D. Inside spread of main beams

Length of main beam

$\mathrm{H}-1$. Circumference at smallest place between burr and first tines

G-1. Length of first tine

G-2. Length of second tine

G-3. Length of third tine

$\mathrm{H}-2$. Circumference at smallest place between first and second tines

$\mathrm{H}-3$. Circumference at smallest place between second and third tines

$\mathrm{H}-4$. Circumference at smallest place between third and fourth tines

G-4. Length of fourth tine, if present

Ei. Abnormal tines

$\mathrm{Cl}(95 \%)$ 95\% Confidence Interval 
Agric. Biol. J. N. Am., 2011, 2(2): 387-400

Table 6. Comparison of antler morphometric values $(\mathrm{cm})$ between the $O$. v. carminis of present study and the reported by Krausman and Ables (1981) and Cienfuegos-Rivas et al. (2008) for O. v. carminis, O. v. couesi and O. v. texanus subspecies (to make comparison possible data from literature was converted to centimeters).

\begin{tabular}{|c|c|c|c|c|c|c|c|c|}
\hline Subspecies & D & $\mathbf{F}$ & G1 & G2 & G3 & H1 & $\mathrm{H} 2$ & Source of data \\
\hline O. v. carminis & 34.49 & 41.48 & 6.76 & 14.68 & 13.06 & 9.70 & 8.33 & Present Study \\
\hline O. v. carminis & 34.59 & 33.68 & 5.77 & 12.27 & 11.20 & 7.95 & 8.86 & Krausman and Ables (1981) \\
\hline O. v. texanus & 46.23 & 56.39 & 10.16 & 21.59 & 20.83 & 10.92 & 9.91 & Cienfuegos-Rivas et al. (2008) \\
\hline
\end{tabular}

D: Inside spread of main beams, F: Length of main beam right and left antler, G: Length of tines (G; $1,2, \ldots \mathrm{n}$ tines ), H: Circumference between tines $\left(\mathrm{H} ; \mathrm{H}_{1}=\right.$ burr and first, $\mathrm{H}_{2}=$ first and second tines) 
Morphometric trend.- morphometric variability is the result of the combination of the deer's genetic constitution and the environment (Heffelfinger, 2006). It also depends on the age at which each variable is measured (Villarreal, 2000; Heffelfinger, 2006). In order to observe the effect of rain on the studied morphometric traits, and the possible association with food availability as well as its effect on deer's growth, this trend was evaluated only for animals between 3.5 and 5 years old (Fig. 4). It was found that deer's body morphometric variables were associated with pluvial precipitation, since rain favors vegetation growth and thus food availability (Hunter and Sulzer 2002) as well as the type, variation and quality of the environment (Geist et al., 2000). If the pluvial precipitation of the previous two years to harvesting is taken into account, when the deer's age was between 1.5 to 3.5 years (growth stage), it can be observed (Fig. 6) that the food availability affected the morphometry of the corporal variables that were measured when deer were 3.5 to 5 years old.

Morphometric Correlation: The correlation between TG and the variables SL, NC, HS, HGC, and $\mathrm{HHL}$ were not significant $(P>0.05)$, while the correlation between TG and the variables JL and TL were -0.36 and 0.39 respectively $(P<0.05)$. Deer's body weight was highly and positively correlated with all the variables $(P<0.05)$ with the exception of $H H L$ with TG that was positive $(0.29)$ but not significant $(P>0.05)$. It is worth to note that the NC was highly correlated with SL, HGC, BW, and the age of the deer, and hence NC could be used as a surrogate of age and body weight of the deer (Table 4a). Morphometric correlations between body and antler variables were, in general, low. Moreover, antler total score (gross) was poorly associated $(0.18 ; \mathrm{P}<0.05)$ with $\mathrm{TL}$ and moderately correlated $(P<0.05)$ with HGC $(0.33)$ and HS (0.25) (Table 4c).

Antler Variables: Regarding to antlers morphometry, coefficients of variation for abnormal tines was observed above $33 \%$. Regarding to antlers morphometry, coefficients of variation for abnormal tines were observed above 33This can be due to simply within-population variation (Heffelfinger, 2006). Nevertheless, it was evident that Wt-Kg was not highly associated with antler traits, with correlations varying from 0.16 to 0.40 (Table $4 \mathrm{~b}$ ). However, the age of the deer was associated with antlers mass ( $\mathrm{H} 1$ circumference between burr and first tine) showing a correlation of $0.51(P<0.05)$, but not with the inside spread of main beams (D) where the correlation observed was 0.29 (Table 4b). The correlation between inside spread of main beams (D) with length of main beams (F) was also positive (0.67) $(P<0.05)$.

The antler morphometric variables found in the present study (Table 6) for adult animals (3.5 a 5.5 years) had larger main beams and more antler mass $(\mathrm{H} 1$; circumference between burr and first tines) than those reported for O.V. carminis in the U.S. (Krausman and Able 1981) and in general, the antler of O.v. carminis was larger than O.v. couesi (Krausman and. Able 1981) but smaller than that of $O, v$, texanus reported by Cienfuegos-Rivas et al (2008).

Being individuals from the same subspecies and from a close geographical distribution range (northeastern Mexico) it would be expected that the general antler structure should be highly similar. Hence, differences could be attributed to antler size and not to antler structure or conformation. Similarly, antler traits depend on heritable and environmental factors which could be expressed, or not, by the chronological and physical stage of a given individual (Lukefahr and Jacobson 1998). Therefore, besides the genetic aspects, food and water availability could improve or diminish the antler size of an individual, as well as the presence of disease or parasites, social competition or other elements affecting one or more individuals (Heffelfinger, 2006).

\section{CONCLUSION}

There were no morphometric differences among the animals harvested along the different studied areas (i.e., vegetation types), suggesting they belong to one single population. The Carmen Mountain white-tailed deer described in the present study in the Coahuila state (northeastern, Mexico), is similar to the one reported in the U.S. but different from subspecies O.v. texanus. Hence, it can be concluded that O.v. carminis deer is a distinctive subspecies.

\section{ACKNOWLEDGEMENTS}

We are thankful to Mrs. Elizabeth Spence Fennell owner of the Rancho La Escondida, for her useful comments, suggestions and measuring the animals, which greatly improved this manuscript, without her help and information this paper could have not been accomplished. We thank Mr. Charles Sellers Thompson for giving us all facilities to have access to the ranch. Special thanks to Marcia Castillo Mendoza for proofreading the manuscript. We thank to Fondos Mixtos-CONACYT (FOMIX) for funding this research (Project Number: TAMPS-2005-C08-06), to ANGADI, 
for giving access to their affiliates records system and finally, to the Universidad Autónoma de Tamaulipas for providing all the means to complete this research.

\section{REFERENCES}

Anthony R.G. and Smith N.S (1997). Ecological Relationships between Mule Deer and White-Tailed Deer in Southeastern Arizona. Arizona Cooperative Wildlife Research Unit. University of Arizona, Tucson. Arizona, USA. Ecological Monographs 47: 255-277.

Brower J.E., Zar J.H., Von-Ende C (1990) Field and Laboratory Methods for General Ecology. 3rd ed. 237. WC Brown Publishers. Dubuque, IA.

Cienfuegos-Rivas E.G., Maldonado G.A., Logan L.A., Gonzalez R.A., Martínez J.C., Zárate F.P. (2008) Variabilidad Morfológica de las Astas del Venado Cola Blanca Texanus en el Noreste de México. CienciaUAT 10:64-67.

Geist, V.B O'Gara and R.S. Hoffmann (2000) Taxonomy and the Conservation of Biodiversity. In Demerais, S and $\mathrm{P}$ Krausman. Ecology and Management of Large Mammals in North America. Prentice Hall, Inc. New Jersery, US pp. 1-37, 233-259, 601-628.

Goldman E.A. and Kellogg R (1940) Ten new white-tailed deer from North and Middle America. Proceedings of the Biological Society of Washington. 53: 81-90.

Halls L.K. (ed) (1984) White-Tailed Deer: Ecology and Management. 870, Stackpole Books, Harrisburg, Pennsylvania.

Harmel D.E. and Litton G.W. (1981) Deer management in the Edwards Plateau of Texas. Texas Parks and Wildlife Department. Austin, Texas, USA.

Heffelfinger J.R. (2006) Deer of the Southwest: A Complete Guide to the Natural History, Biology, and Management of Mule Deer and White-Tailed Deer. 282, Texas A \& M University Press, Texas, USA.

Hunter-Jr L.M. and A Sulzer (2002) Fundamental of Conservation Biology. 2nd ed. 547. Blackwell Science, Inc. USA.

Jacobson H.A. Reiner R.J. (1989) Estimating Age of Whitetailed Deer: Tooth Wear Versus Cementum Annuli, Southeastern Association of Fish and Wildlife Agencies; Vol. 43; 286-291; In: Proceedings of the 43rd Annual Conference Southeastern Association of Fish and Wildlife Agencies (October 29-November 1, 1989, St. Louis, Missouri)

Kellogg R (1956) What and where are the whitetails?. 31 55 In: The Deer of North America. Taylor WP (ed). The Stockpole, Wildlife Management Institute, Washington DC, USA.

Krausman P.R. and Ables E.D. (1981) Ecology of the Carmen Mountains White-Tailed Deer. 114. Scientific Monograph Series $N^{\circ} 15$, National Park Service, US Department of the Interior, Washington DC, USA.
Kramer A (1972) A Review of the ecological relationships between mule and white-tailed deer. Alberta Department of Land and Forest. Wildlife Tech. Bull. 3:48.

Kroll J.C. (1992) A Practical Guide to Producing and Harvesting White-Tailed Deer. Institute of White Tailed Deer Management and Research Center for Applied Studies Forestry, Stephen F. Austin State University, Texas, USA.

Logan L.K. (2004) Caracterización Genética y Morfométrica de cuatro Subespecies de Venado Cola Blanca (Odocoileus virginianus) en la Zona CentroNorte del Noreste de México. Tesis de Maestro en Ciencias. Colegio de Postgraduados, Texcoco, México.

Logan L.K., Cienfuegos-Rivas E, Sánchez F.C., Mendoza G.D., Sifuentes A.M. y Tarango L.A. (2006) Caracterización Morfométrica de Cuatro Subespecies de Venado Cola Blanca (Odocoileus virginianus) en la Zona Noreste de México. FCV-LUZ 15: 14-22.

Logan-López Karla, Cienfuegos-Rivas Eugenia, SifuentesRincón Ana, González Pazo Mauricio, ClementeSanchez Fernando, Mendoza-Martínez German, y Tarango-Arámbula Luis. (2007). Patrones de Variación Genética en Cuatro Subespecies de Venado Cola Blanca del Noreste De México. AGROCIENCIA 41: 1321

Lukefahr S.D. and Jacobson H.A (1998) Variance Component Analysis and heritability of Antler Traits in White-tailed Deer, Journal of Wildlife Management 62(1): 262-268.

Lundrigan B (1996) Standard methods for measuring mammals. In: Kleiman DG, Allen ME, Thompson K and Lumpkin S (eds) Wild Mammals in Captivity Principles and Techniques. 566-570. The University of Chicago Press, Chicago, USA.

Miller K.V. and Marchinton R.L. (eds) (1995) Quality whitetails: the why and how of quality deer management.169-189. Stackpole Books, USA.

Villarreal J.G. (1995) Sinopsis geográfica, situación actual y posibilidades de recuperación de las subespecies mexicanas de venado cola blanca Odocoileus virginianus. Memoria del XIII Simposio sobre Fauna Silvestre. Facultad de Medicina Veterinaria y Zootecnia. Universidad Nacional Autónoma de México. DF, Mexico.

Villarreal J.G. and Martínez A.M. (1997) Bases para el Manejo del Venado Cola Blanca Odocoileus virginianus con Fines de Aprovechamiento Cinegético. 139. Asociación Nacional de Ganaderos Diversificados Criadores de Fauna. Tamaulipas, Mexico.

Villarreal J.G. (2000) Venado Cola Blanca Manejo y Aprovechamiento Cinegético, 1st ed. 401. Unión Ganadera Regional de Nuevo León. Nuevo León, Mexico. 